\title{
Effect of Foliar Application with Potassium, Calcium and Magnesium on Yield, Fruit Quality and Mineral Composition of Washington Navel Orange Trees
}

\author{
M.M.El-Tanany; M.N.Abdel Messih ${ }^{1}$ and M.A.Shama ${ }^{2}$
}

\begin{abstract}
A field experiment was conducted during 2008 and 2009 growing seasons in sandy soil of Bustan area, Tawfik EL- Hakem village, Behera governorate, Egypt. The objective of this study was to evaluate the influences of foliar application with mixture of potassium, calcium and magnesium on fruit set, fruit growth rate, fruit splitting, yield and fruit quality of Washington Navel orange trees. The tested variables were: $T_{1}$ : Control (Only Sprayed with tap water).T2, T3 and T4: Trees sprayed with $300 \mathrm{ppm}$ liquid potassium plus $100 \mathrm{ppm}$ chelated calcium plus 20 ppm magnesium sprayed once; on May, 10, twice; on May, 10 and June, 10 and thrice, on May, 10, June, 10 and July, 10 respectively. T5, T6 and T7: Trees sprayed with 600 ppm liquid potassium plus 200ppm chelated calcium plus 40ppm magnesium also sprayed at the same dates mentioned above. Mature (6 years old) of Washington Navel orange budded on sour orange rootstock and spaced at $5 \mathrm{~m}$ apart were used. Results indicated that spraying Washington navel orange trees with potassium, calcium and magnesium once, twice or thrice with two concentrations resulted in a higher number of fruit set / branch, number of fruits/ tree and yield. Different spraying treatments increased fruit growth rates, fruit weight, diameter, rind thickness and juice volume. Fruit acidity and T.S.S. was increased only in one season, while, fruit length and Vitamin $C$ content was not affected. The results also showed a marked decrease in fruit splitting percentage. Different foliar applications increased potassium, calcium and magnesium in the leaves.
\end{abstract}

\section{INTRODUCTION}

Citrus occupies the largest fruit trees area in Egypt. Washington Navel orange is considered the most popular and widespread citrus variety. Efforts have been intensified to improve the cultural practices in order to raise citrus yield per acre. One of the most important cultural practices is the fertilization program. Foliar fertilizer rates are typically lower than soil fertilizer rates, but applications can be more costly. These applications which added only minimally to production costs, were able to increase returns by several pounds per acre per year. Foliar fertilization also reduces nutrient accumulation in soil, groundwater, where they contribute to salinity with negative consequences to humans and environment. Nutritional need for potassium centers on four physiologicalbiochemical roles, enzyme activation, membrane transport process, anion neutralization and osmotic potential (Clarkson \& Hanson, 1980). Potassium is also important in formation and functioning of proteins, fats, carbohydrates and chlorophyll and in maintaining the balance of salts and water in plant cells, (Achilea, 1998).

Calcium element builds and strengthens the cell wall membrane in plants. Cell wall membrane surrounds the cytoplasm of cell and helps in maintaining the structure and shape of the cell. Reduction of calcium element in the cell causes holes or cracks in the cell walls which allows the salts concentrations in the cytoplasm to flow out from the cell. Calcium salts are also able to prevent a few plant diseases. Calcium promotes early root formation and growth, improves general plant vigor, stiffness of stalks and improves fruit integrity. Calcium also influences the uptake of other nutrients such as phosphorous, manganese, iron, zinc and boron, (Polevoiy, 1989).

The first important property of magnesium is the relatively high solubility of its salts. Magnesium has a structural role in chlorophyll, is required for ribosome integrity, and undoubtedly contributes to the structural stability of nucleic acids and membranes, (Clarkson and Hanson, 1980). Foliar application of potassium, calcium and magnesium on citrus was found to increase yield and improve fruit properties; specially when sprayed during the proper period of growth (Maksoud et al., 2003), Boman 2001, Cicala and Catara 1994 and Boman, 2002). Abd-Allah, 2006, reported that, combination between nutrients i.e $\mathrm{Ca}$ chelate $0.5 \%$ + dipotassium hydrogen phosphate $1 \%$ significantly improved the yield of Washington navel orange trees. Yaseen and Manzoor, 2010 reported that NPK fertilizers (calculated on the basis of age and foliage rather than on the basis of area) application in drip line in combination with foliar spray was helpful to improve production and quality of Kinnow mandarin fruits up to $63 \%$.

\footnotetext{
${ }^{1}$ Sabahia Horticulture Research Station, Alex.,

Horticulture Research Institute,ARC, Egypt.

${ }^{2}$ Soil Salinity laboratory, Alex., Soil, Water and Environment Res.

Institute, ARC, Egypt.

Received March 1, 2011, Accepted March 30, 2011
} 
The goal of the present study is to determine the proper time to apply foliar potassium, calcium and magnesium at specific growth stages of Washington Navel orange trees, when nutrient demand is likely high, to increase yield, fruit size and quality, such that foliar fertilization to increase grower's income.

\section{MATERIALS AND METHODS}

The present investigation was conducted in a private orchard located at Tawfik El-Hakem village. Bustan area, Behera governorate, Egypt during the 2008 and 2009 seasons. The main goal of this study was to evaluate the influences of foliar application with mixture of potassium, calcum and magnesium on fruit set, fruit growth rate fruit splitting, yield and fruit quality of Washington Navel orange trees (Citrus sinensis, L., Osbeck).

Mature Twenty eight trees (6years old) of Washington Navel orange budded on sour orange (Citrus aurantium, L.) rootstock were used in this study, the selected trees were nearly uniform in vigor and size and spaced at $4 \times 5 \mathrm{~m}$ apart (200 trees/Fed.) and received the same cultural practices usually adopted for this area according to the recommendation of Horticulture Research Institute, Ministry of Agriculture, Egypt. Surface drip irrigation system was used in the orchard. Trees received $6500 \mathrm{~m}^{3}$ of water per feddan per year distributed through the whole year. The fertigation program included $400 \mathrm{Kg}$ nitrogen as ammonium sulfate, $200 \mathrm{~kg}$ potassium as potassium sulfate and 32 $\mathrm{kg}$ orthophosphoric acid per feddan per year distributed from February till October. Besides, the trees were also sprayed with Crystalon (19:19:19 N,P,K) only once; at bud sprouting in March at the rate of $4 \mathrm{Kg} / 600$ liters water. In addition, trees were sprayed with $(250 \mathrm{gm}$ chelated iron $8 \%, 250$ gm chelated manganese $14 \%$, $150 \mathrm{gm}$ chelated zinc $13 \%$ and $3 \mathrm{~kg}$ urea $/ 600$ liter of water) three times; at bud sprouting; in March, after fruit set; in May and during fruit growth; in August.

1) Control, (only sprayed with tap water).

2) Trees sprayed with 300 ppm liquid potassium plus $100 \mathrm{ppm}$ chelated calcium plus 20ppm magnesium sprayed once; on May, 10.

3) Trees sprayed with $300 \mathrm{ppm}$ liquid potassium plus $100 \mathrm{ppm}$ chelated calcium plus 20ppm magnesium sprayed twice; on May, 10 and June, 10.

4) Trees sprayed with $300 \mathrm{ppm}$ potassium solution plus $100 \mathrm{ppm}$ chelated calcium plus 20ppm magnesium solution sprayed thrice, on May 10, June,10 and July, 10 .

5) Trees sprayed with 600ppm liquid potassium plus 200ppm chelated calcium plus 40ppm magnesium solution sprayed, once; on May ,10.
6) Trees sprayed with $600 \mathrm{ppm}$ potassium solution plus 200ppm chelated calcium plus 40ppm magnesium solution sprayed, twice; on May, 10 and June,10.

7) Trees sprayed with $600 \mathrm{ppm}$ potassium solution plus 200ppm chelated calcium plus 40 ppm magnesium solution sprayed, thrice; on May, 10, June, 10 and July, 10 .

Four replicates were selected to represent each treatment. Different treatments were applied using a 20 liters hand sprayer on the foliage until drip point of the solution. Each tree received (5 liters of spraying solution), containing from 1 to $2 \mathrm{~cm}^{3}$ liquid fertilizer under name Tetrax -Potash $\left(30 \% \mathrm{k}_{2} \mathrm{O}, 4 \%\right.$ Citric acid and $2 \% \mathrm{MgO}$ ) as a source of potassium and magnesium. Chelated calcium (at concentration $20 \% \mathrm{Ca}$ ) was added; i.e the addition rate were 1.5 to $3 \mathrm{gm}$ potassium, 1 to $2 \mathrm{gm}$ chelated calcium and 0.1 to $0.2 \mathrm{gm}$ magnesium per tree. Different treatments were repeated on the same trees for two successive experimental seasons.

\section{A. Tissue analysis}

Leaf samples of 30-40 full-expanded mature leaves were taken from non- fruiting shoots of the previous spring growth flushes. The leaves were collected from allover the circumference of each tree. Leaf samples were taken at random after 20 days from last application date. These samples were washed with tap water, rinsed three times in distilled water, oven dried at $65-70 \mathrm{C}^{\circ}$ to a constant weight and grounded to 20 mesh size. Leaf samples were used for calcium, magnesium and potassium determination. As for calcium, magnesium and potassium determination, $0.3 \mathrm{gm}$. ground dry material was digested with sulfuric acid and hydrogen peroxide according to Evenhuis and DeWaard (1980). In digested solution of each sample, calcium and magnesium were determined by the Versenate method using eirochrom black $\mathrm{T}$ and ammonium purpurate indicator for calcium plus magnesium and calcium, respectively (Cheng and Bray, 1951). Potassium was measured against a standard using Carlzesis Jena Flame Photometer.

\section{B. Fruit set number:}

During May, June and July of 2008 and 2009 seasons, two branches located in two different directions (in north east and south west) were tagged from each tree. The circumference of chosen branches was $4-5 \mathrm{~cm}$. The number of setted fruits was recorded in three different counting dates i.e $25^{\text {th }}$ May and $10^{\text {th }}$ of both June and July.

\section{Fruit diameter}

During both experimental seasons, four fruits were randomly selected and tagged on each tree; fruit diameter was measured and recorded monthly on $10^{\text {th }}$ of 
August, September, October and November of each season.

\section{Fruit splitting, fruit number and yield}

During November of 2008 and 2009 seasons, number and percentages of splitted fruits / tree were recorded and calculated. In addition, fruit number of each tree of both experimental seasons was recorded on December, 25. Average fruit weight; of 10 mature fruits randomly selected was estimated for each tree. Fruit yield of each experimental tree was then calculated as $\mathrm{Kg}$ per tree.

\section{G. Fruit quality}

At harvest time (on January, 10) of both seasons, fruit length, diameter and rind thickness of three fruits, randomly taken from each experimental tree, were determined. Total soluble solids content (TSS) in fruit juice was determined by hand refractometer. Fruit volume was also recorded. Acidity, as citric acid percent was determind using $0.1 \mathrm{~N}$ sodium hydroxide. Vitamin $\mathrm{C}$ content in the juice was estimated by titration with 2,6 dichlorophenol endophenol dye (A.O.A.C 1985). The data were statistically analyzed using a Complete Randomized Block Design according to Gomez and Gomez (1984).

\section{RESULTS AND DISCUSSIONS}

Effect of foliar application with potassium, calcium and magnesium on number of fruit set/branch and number and percentage of splitting fruits of Washington Navel orange:

Average number of fruit set/branch is presented in Table (1). The data showed that, in the first season, spraying once in May, with both concentrations, gave the highest number when compared with the control or the three additions during May, June and July and the differences were significant. Approximately similar results were obtained in the second season where spraying in May with low concentration and twice in May and June with high concentration increased the number of fruit set when compared with the control. Boman, 2001, reported that foliar spray with potassium nitrate, monopotasium phosphate, calcium nitrate produced more Valencia orange fruits/tree. Moreover, (Abd- Allah 2006) in Egypt reported that, boric acid+ calcium and boric acid $+\mathrm{K}_{2} \mathrm{HPO} 4$ treatments when sprayed on Washington navel orange trees gave the higher numbers of fruit set per branch. Chapman, 1968 reported that potassium fertilization increases fruit production of citrus up to leaf contents of $1.5-1.7 \% \mathrm{k}$. On the other hand, EL-Shafey et al, 2002 reported that calcium treatments had no significant effect on fruit yield, except 126ppm which decreased fruit weight.
Fruit splitting number and percentage presented in Table (1) clearly revealed that all treatments signficantly reduced fruit splitting when compared with the control. Intrigliolo et al., (1991), working on Navelina orange, found that the effect of potassium on splitting disorder was not marked, but was observed in 1988 season when foliar potassium levels were slightly lower in trees with the greatest incidence of splitting. They added that both potassium and nitrogen appear to play a positive role in preventing splitting. El- Shafey et al., (2002) reported that calcium concentrations, 84 and $126 \mathrm{ppm}$, at all foliar application dates increased fruit pull force and fruit firmness of Valencia orange proportionally.

\section{Effect of foliar application with potassium, calcium and magnesium on fruit growth rates:}

Fruit diameter measurements presented in Table(2) showed that foliar spraying, when done thrice using both concentrations, increased fruit diameter on all measuring dates when compared with the control. The results also revealed that, on the last date of measuring, November, 10, fruit diameter of all treatments was more than that of the control, except spraying once; on May using the first concentration and twice; in May and June using the second concentration. Gill et al., (2005), Sangwan et al., 2008 and Rattanpal et al., (2008).reported that foliar application of potassium increased fruit size of Kinnow mandarin, enhancing the "A" grade fruits compared to the control. Boman, (2001) in Florida using Valencia orange, Huang et al., (1995) in China using Satsuma mandarin and Quaggio et al., (2002) using Sicilian lemon in Brazil reported that potassium fertilizers increased fruit size. On the other hand, Miller et al,. (1998) using Valencia and Robyn Navel oranges in South Africa reported that spray applications of potassium fertilizer did not significant affects fruit quality parameters including size.

Effect of foliar application with potassium, calcium and magnesium on fruit weight, number/tree and yield of Washington Navel orange trees.

The results shown in Table (3) indicate that, in both seasons, all treatments gave higher number of fruits/tree when compared with the control. However spraying thrice in the first season and twice in the second one gave almost the highest number of fruits/ tree. As for the effect of different foliar applications on average fruit weight the results indicated that, in the first season, fruits produced from trees sprayed once, twice or thrice with the second concentration, (600ppm K $+200 \mathrm{ppm} \mathrm{Ca}$ $+40 \mathrm{ppm} \mathrm{Mg}$ ) were heavier than those of the other treatments and the control. 

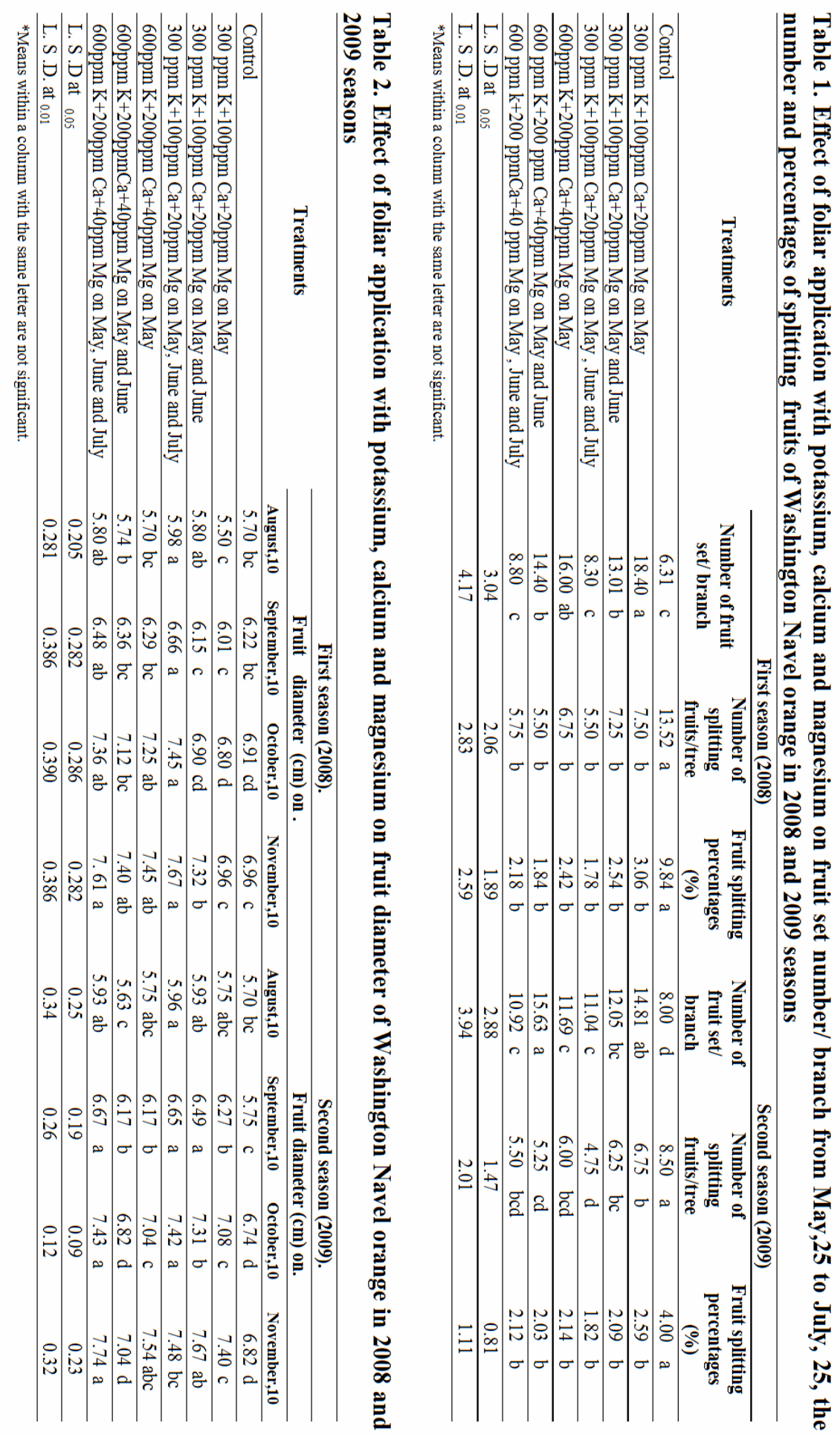
Approximately similar results were obtained in the second season except that of three times applications trial, using the first concentration $(300 \mathrm{ppm} \mathrm{K}+100 \mathrm{ppm}$ $\mathrm{Ca}+20 \mathrm{ppm} \mathrm{Mg}$ ) which produced heavier fruits when compared with the control.

The effect of different foliar application treatments on yield clearly showed that all treatments increased yield of the trees when compared with the control. It was also noticed that the increase in yield is mostly attributed to the increase in number than in the weight of the fruits. These results agree with those obtained by Maksoud et al., (2003) using Balady mandarin trees and Boman (2001) using Valencia orange trees, who reported that potassium foliar application increased citrus yield. Increasing citrus yield when the trees were sprayed with magnesium salts was reported by many investigators, Haggag et al., (1987) Dawood et al.(2001) Calver and Reitz, (1966) Koo and young, (1969). Hoffmann and lacey,( 2009) and El-Fouly et al., (2010) On the other hand, Cicala and Catara, (1994) in Italy reported that there was a significant negative correlation between leaf potassium and yield of Taroccs orange trees.

Effect of foliar application with potassium, calcium and magnesium on physical fruit properties of Washington navel orange trees.

No clear trend was shown regarding fruit length according to different spraying treatments, (Table 4). As for fruit diameter, in the first season, the results revealed a slight increase in fruits of trees sprayed thrice with the first concentration i.e 300ppm $\mathrm{K}+100 \mathrm{ppm} \mathrm{Ca}$ $+20 \mathrm{ppm} \mathrm{Mg}$, when compared with other treatments except those of the control. These results can be attributed to the lower number of fruits produced by the control trees (Table 3). Approximately similar results were obtained in the second season, where fruit diameter of trees sprayed thrice with both concentrations and the control was higher than that of the other treatments.

The increment in fruit size due to potassium and magnesium application to citrus trees was reported by Huang et al., (1995) in China using Satsuma mandarin, Boman, (2001) in Florida using Valencia orange, Quaggio et al.,(2002) in Brazil using Sicilian lemon, Rattanpal et al., (2008) using Kinnow mandarin and Dawood et al., (2001) in Egypt using Washington navel orange trees . On the other hand, Miller and Bird, (1998) using Midknight Valencia orange and Robyn Navel in South Africa found that spray applications of potassium fertilizers did not significant effects on fruit quality parameters including size.
Regarding rind thickness, results presented in Table (4) showed that spraying twice, using both concentrations, in both seasons, mostly resulted in thicker rind when compared with other treatments or the control. Gill et al., (2005) in India reported that foliar potassium treatments significantly increased peel thickness of Kinnow mandarin fruits. In addition, Goepfert et al., (1987) working on Valencia orange reported that potassium increased peel thickness. Young Ho et al.; (2004) in Korea found that foliar application with some calcium formulae in Satsuma mandarin caused the thickest peel. On the other hand, Lavon et al.(1995) working on Star-Ruby grapefruit reported that foliar spray with monopotassium phosphate (MKP) gave thinner peel than that of untreated trees while flesh diameter was significantly greater.

Results shown in Table (4) revealed that juice volume of fruits produced from all treatments was significantly higher than that of the control. However, spraying once and twice using the first concentration and thrice using the second concentration were more effective when compared with the control. The results in the second season showed that spraying twice, on May and June, with both concentrations was significantly more effective than that of the control. The effect of potassium on increasing juice volume of citrus fruits was reported by Lavon et al.(1995) using StarRuby grapefruit; and Maksoud et al.(2003) in Alexandria, Egypt working on Balady mandarin trees; Miller et al., (1998) using Midknight Valencia and Robyn Navel reported that spray application of potassium fertilizers gave no significant effect on fruit quality including juice content. On the other hand, Cicala and Catara, (1994) in Italy working on Tarroco orange trees and Gill et al.(2002) in India, using Kinnow mandarin; found that foliar application of potassium decreased juice volume

\section{Effect of foliar application with potassium, calcium and magnesium on chemical properties of Washington navel orange fruits.}

The results shown in Table (5) indicated that different foliar spraying treatments did not affect vitamin $\mathrm{C}$ content of the fruits in both seasons of the study. These results disagree with Ali and Gobran, (2002) in Egypt working on Washington navel orange trees, Gill et al., (2005) in India using Kinnow mandarin trees and Rattanpal et al., (2008) working on Kinnow mandarin. They reported that foliar application of potassium increased vitamin $\mathrm{C}$ content of citrus fruits. Haggag et al., (1987) and Dawood et al.,( 2001) both working on Washington navel orange trees in 

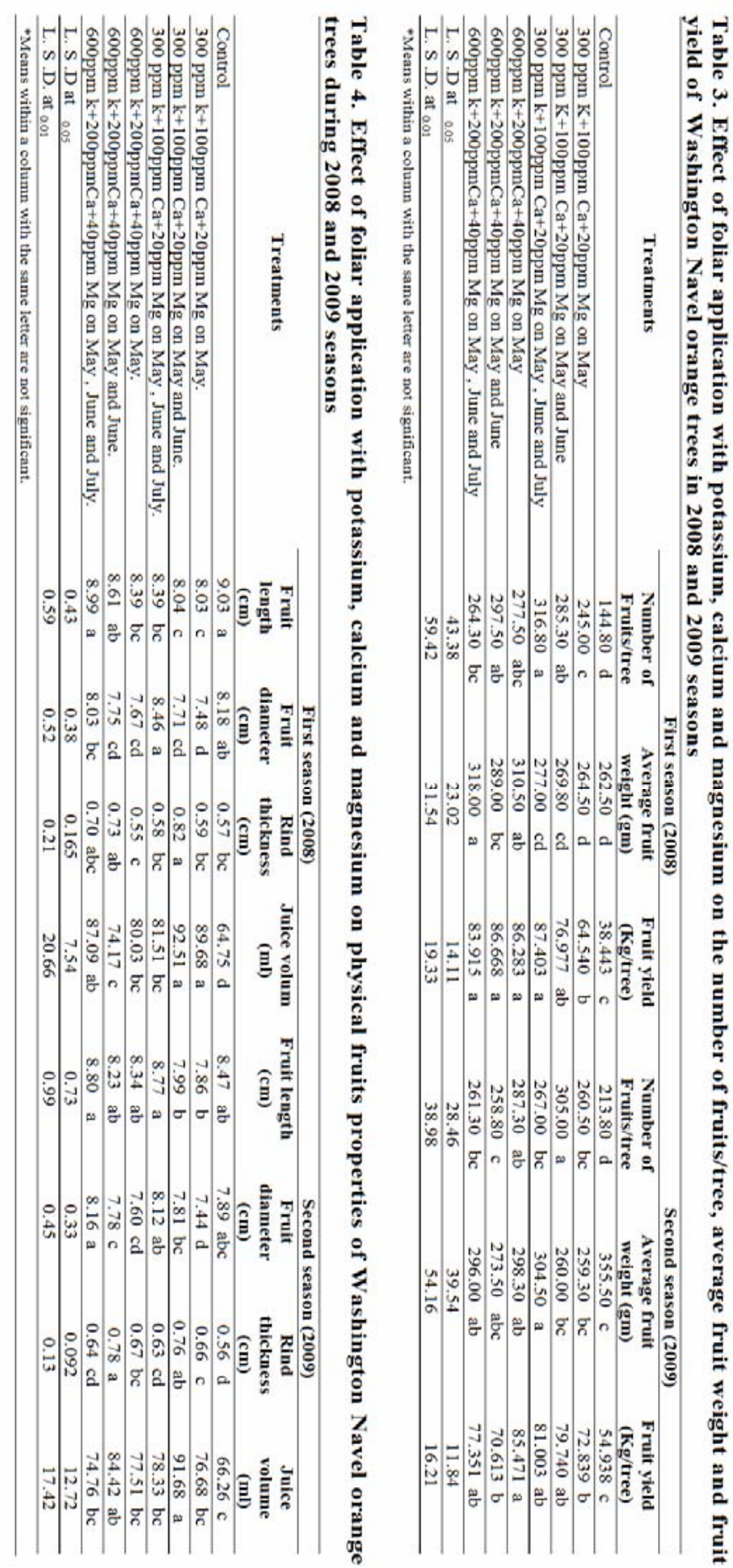
Egypt found that magnesium foliar application increased Vitamin $\mathrm{C}$ content of citrus fruits. The effect of different foliar application treatments on juice acidity is shown in Table (5). The results revealed that, in the first season, relatively higher valueswere found in fruits of trees sprayed once in May using both concentrations. However, this effect was not clear in the second one.

Increasing acidity of citrus fruits, due to foliar application with potassium, was reported by Gill et al., (2005) and Rattanpal et al., (2008) both working on Kinnow mandarin, Increasing citrus fruits acidity by foliar magnesium application was also reported by Haggag et al., (1987) in Egypt working on Washington navel orange trees. On the other hand, Cicala and Catara, (1994) in Italy using Tarocco orange trees and Miller et al,, (1998) in South Africa working on Midknight Valeucia and Robyn navel orange trees, found that potassium foliar application did not affect fruit acidity.

As for total soluble solids percentage, Table (5) shows that, in the first season, spraying once or twice, using both concentrations, gave higher values than that of the control fruits. However, spraying thrice on May, June and July resulted in a less pronounced effect. The results of the second season showed that, except spraying once on May using the first concentration, total soluble solids in the fruits of all other treatments were statistically similar to that of the control. Increasing T.S.S of citrus fruits according to potassium foliar spray was reported by Boman, (2001) in Florida working on Valencia orange and Gill et al., (2005) in India using Kinnow mandarin. Calcium, when sprayed on Satsuma mandarin trees in Korea, was also found to increase T.S.S. of the fruit, (Young Ho et al., 2004). Other investigation, reported that potassium foliar spray did not affect T.S.S. of citrus fruits, Reitz and koo, (1960), Miller et al.,(1998) and Gill et al., (2002). Calcium when sprayed to citrus trees has no effect on fruit T.S.S., Yong Ho and Myung , (1999) in Korea working on Satsuma mandarin and El-shafey et al., (2002), in Egypt using Valencia orange trees. Similar conclusion was also reported by Haggag et al., (1987) when magnesium was sprayed on Washington navel orange trees in Egypt.

Effect of foliar application with potassium, calcium and magnesium on leaf mineral content of Washington navel orange trees.

The results of Table (6) showed that foliar spraying with potassium liquid solution, generally resulted in increases in leaf potassium content compared with that of the control. In the first season, however, leaves collected from trees sprayed once, twice and thrice using the higher concentration, were markedly higher than that of other treatment including the control. The results of the second season showed that trees sprayed twice or thrice using the high concentration, markedly increased leaf potassium content compared with the control.

Increased leaf potassium of citrus leaves when the trees sprayed with potassium solution was reported by Ebrahiem et al. (1993), Lavon et al., (1995), Cicala and Catara, (1994), Goepfert et al., (1987),Boman, (2002), Boman, (2001) and Abd-Allah, (2006).

Calcium concentration, in the first seasons, in all leaves collected from trees sprayed with chelated calcium once in May or thrice in May, June and July using high concentration, was significantly higher than that of the control. However, this effect was not high enough to be significant in the leaves of trees sprayed twice in May and June using both concentrations (Table 6 ). The results of the second season showed an increase in calcium concentration in all leaves of trees sprayed with chelated calcium. However, this effect in the leaves of trees sprayed twice or thrice using the first concentration was not high enough to be significant. Young Ho et al.; (2004) in Korea reported that foliar application of calcium salts on Satsuma mandarin trees did not affect calcium concentration in the leaves.

As for magnesium, the results revealed that all leaves collected from all sprayed tree contained higher magnesium content when compared with those of the control. However, the differences were statistically significant only in leaves of trees sprayed once or thrice using the higher concentration (Table 6). The results of the second season were mostly similar to that of the first season i.e the leaves of all trees which received foliar spray contained higher magnesium concentrations when compared with that of the control, while the differences were only significant in those collected from trees sprayed twice or thrice using the first concentration, and once and thrice using the higher concentration, (Table 6).

Increased leaf magnesium of citrus leaves when the trees were sprayed with magnesium salts was reported by Haggag et al., (1987), El-Fouly, et al., (2010), Calvert and Reitz, (1966) and Young, (1969).

\section{CONCLUSION}

From the results of the present study, it can be concluded that foliar application with potassium, calcium and magnesium to Washington navel orange trees once, twice or thrice with both concentrations; $300 \mathrm{ppm} \mathrm{K}+100 \mathrm{ppm} \mathrm{Ca}+20 \mathrm{ppm} \mathrm{Mg}$ and 600ppm $\mathrm{K}+200 \mathrm{ppm} \mathrm{Ca}+40 \mathrm{ppm} \mathrm{Mg}$ resulted in a high number of fruit set / branch, number of fruits/ trees and yield. Moreover, different spraying treatments increased fruit growth rates and leaves content of potassium, calcium 

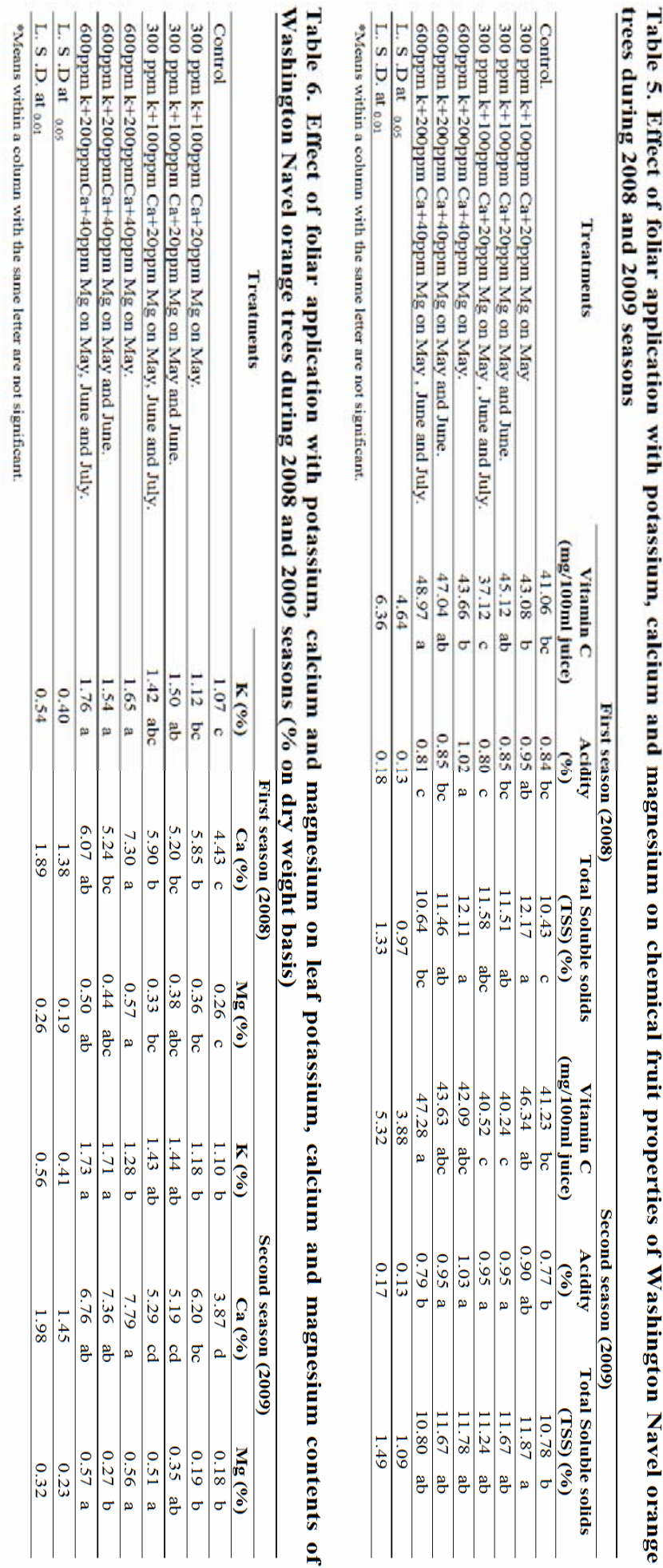
and magnesium and decreased markedly fruit splitting percentage and also improved of fruit quality, except vitamin $\mathrm{C}$ content which was not affected.

\section{EFERENCES}

Abd-Allah, A.S.E.(2006). Effect of spraying some macro and micro nutrients on fruit set, yield and fruit quality of Washington Navel orange trees. J. of Applied Sciences Research, 2 (11): 1059-1063.

Achilea, O. (1998). Citrus and tomato quality is improved by optimized K nutrition. In: Improved Crop Quality by Nutrient Management. Anac, D. and P. Martin - prevel (eds). Kluwer Academic Publishers. PP: 19-22.

Ali, M.A. and Y.N. Gobran (2002). Effect of soil moisture regimes and potassium application on growth, yield and fruit quality of Washington navel orange trees. Annals of Agricultural Science, Moshtoher. 40(3): 1669-1697.

A.O.A.C.(1985). Official methods of analysis of the Association of Official Agricultural Chemists. Published by the A.O.A.C. $14^{\text {th }}$ Ed. Washington. D.C.

Boman, B.J. (2001). Foliar nutrient sprays influence yield and size of 'Valencia' orange Proc. Fla. State Hort. Soc., 114:83-88.

Boman, B.J.(2002). $\mathrm{KNO}_{3}$ foliar application to 'Sunburst' Tangarine. Proc. Fla. Hort. Soc. 115:6-9.

Calvert, D.V. and H.J. Reitz (1966). Response of citrus growing on calcareous soil to soil and foliar applications of magnesium. Flor. State Horticultural Society. Fort Pierce No. 2527: 1-6.

Chapman, H.D.(1968). The mineral nutrition of Citrus. PP. 127-289 In: The citrus Industry (Ed:W. Reuther). Vol. 11 Revised edition, University of California Press Berkeley, C A, USA.

Cheng, K.L. and R.H. Bray (1951). Determination of calcium and magnesium in soil and plant material. Soil Sci., 72:449-458.

Cicala, A. and V. Catara (1994). Potassium fertilization effects on yield, fruit quality and mineral composition of leaves of Tarocco orange trees. Proceeding of the International Society of Citriculture: Volume 2. Cultural practices, diseases and their control: $7^{\text {th }}$ International Citrus congress, Acireale, Italy, 8-13 March, 19921994,618-620.

Clarkson, D.T. and J.B. Hanson (1980). The mineral nutrition of higher plants. Ann. Rev. Plant Physiol., 31:239-298.

Dawood, S.A.; M.M. El-Hamady; S.A.G. El-Siada and A.M.Hamissa (2001). Response of Washington Navel orange trees grown on slightly alkaline clay soils to magnesium rate, methods and number of applications. Egyptian Journal of Agric. Res. 79(3):1059-1073.

Ebrahiem, T.A.; F.F. Ahmed and K.G. Assy (1993). Behaviour of Balady mandarin trees (Citrus reticulate L.) grown in sandy soil to different forms and concentrations of potassium foliar sprays. Assiut Journal of Agricultural Sciences. 24 (3): 215-227.
El-Fouly, M.M; A.I. Rezk; O.A. Nofal and E.A.A. Abou ElNour (2010). Depletion of magnesium in Egyptian soils, its content in crops and estimated needs. African Journal of Agricultural Research. 5(10):1060-1067, 18 May.

El-Shafey, Y.H.; A.M.A. El-Rahman and A.M. EL-Azaze (2002). Effect of foliar application with calcium on yield and fruit quality of Valencia orange trees. Bulletin of Fac. of Agric, Cairo Univ. 53(2):275-288.

Evenhuis, B and P.W. De Waard De (1980) Principles in plant Analysis FAO Soil Bull. 39:152-162.

Gill, P.S.; S.N. Singh and A.S. Dhatt (2002). Fruit quality of Kinnow mandarin in response to foliar application of $\mathrm{k}$ and $\mathrm{N}$ fertilizers. Indian Journal of Horticulture. 1 (2):150153.

Gill, P.S.; S.N. Singh and A.S. Dhatt (2005) Effect of foliar application of $\mathrm{K}$ and $\mathrm{N}$ fertilizers on fruit quality of Kinnow mandarin. Indian Journal of Horticulture. 62(3):282-284.

Goepfert, C.F.; E.L.S. de Saldanha and O. de M.porto (1987). The response of Valencia orange (Citrus sinensis, Osb.) to fertilizer levels, average of eight harvests. Agronomia Sulriograndense . 23(2):203-215.

Gomez, K.A. and A.A. Gomez (1984). Statistical Procedures for Agricultural Research. $2^{\text {nd }}$ ed. John Wiley and Sons. New York, U.S.A.

Haggag, M.N.; H.A. El-shamy and E.M. El-Azab (1987). Magnesium influences on leaf chlorophyll, leaf mineral composition, yield and fruit quality of Washington Navel oranges in Egypt. Alex. J. of Agric Res.32(3): 189-198.

Hoffmann, H. and K.Lacey (2009). Citrus disorders. Department of Agriculture and Food. December 2009. Note 384:1-4.

Huang, F.S.; H.S. Zhang; H.M. Qian and F. Yi (1995). Study on the effects of organic manures and leaf spraying $P$ and $\mathrm{k}$ on the fruit quality of extra-early Satsuma mandarin . China Citrus. 24(2):31-32.

Intrigliolo, F.; V. de Cicco; S. Vanadia; A. Ippolito and A. Giuffrida (1991). Effect of water stress and potassium on 'Navelina' orange splitting. Agricoltura Mediterranea. 121(1):24-31.

Koo, R.C.J. and T.W. Young (1969). Correcting magnesium deficiency of lime grown on calcaresus soils with magnesium nitrate. Flor. Stat. Hort. Soc., Flor. Agric. Exper. Station J. Series No. 3390:274-278.

Lavon, R.; I.Horesh; S.Shapchiski; E.Mohel and N. Zur (1995). Influence of foliar spray with monopotassium phosphate (MKP) on the yield, fruit size and fruit quality of Star-Ruby grapefruit. Alon Hanotea. 49(4):172-176.

Maksoud, M.A.; M.M.S. Saleh; L.F.Haggag and B.N.Boutros (2003). Effects of iron and potassium fertilization on Balady mandarin trees grown in calcareous soil. Annals of Agricultural Science (Cairo). 48 (2):741-746.

Miller, J.; J. maritz and P.Bird (1998). Could potassium be used to improve Midknight Valencia and Robyn Navel. Neltropika Bulletin. 302:32-33. 
Polevoiy, V.V. (1989). Calcium-related physiological disorders of plants. Ann. Rev. Phytopathol. 17:97122.

Quaggio, J.A., D.Mattose Jr.; H.Cantarella, E.L.E. Almeida and S.A.B. Cardoso (2002). Lemon yield and fruit quality affected by N P K fertilization. Scientia Horticulturae. 96:151-162.

Rattanpal, H.S.; S.Rani and H.S.Dhaliwal (2008). Effect of potassium and 2,4-D on yield and fruit quality of Kinnow mandarin. Environment and Ecology. 26(2):709-715.

Reitz, H.J. and R.C.J. Koo (1960). Effect of nitrogen and potassium fertilization on yield, fruit quality and leaf analysis of Valencia orange. J. Amer. Soc. Hort. Sci. vol. 75:244-252.

Sangwan, A.K.; H.S. Rattanpal; N.K. Arora and R.S. Dalal (2008). Effect of foliar application of potassium on fruit yield and quality of Kinnow mandarin. Environment and Ecology. 26:4C,2315-2318.
Yasseen. M. and A.Manzoor (2010). Nutrition management in citrus: Effect of multinutrients foliar feeding on the yield of Kinnow at different locations. Pak. J. Bot., 42 (3):18631870.

Young Ho, K. and K.C. Myung (1999). Effect of calcium formulate foliar sprays on the fruit quality of Satsuma mandarin (Citrus Unshiu, Mac.) in a plastic film house. Journal of the Korean Society for Horticultural Science. 40 (1): 88- 92.

Young Ho, K.; M.Young Eel and H. Seung Gab (2004). Effect of calcium formulae foliar application on the water spot out break and fruit quality of Satsuma mandarin in the plastic house. Korean Journal of Hort. Sci. \& Technology .22(1):50-54. 


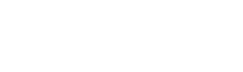

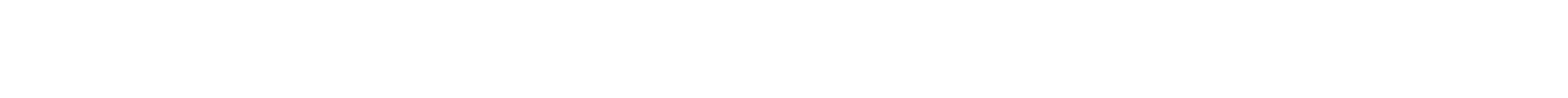

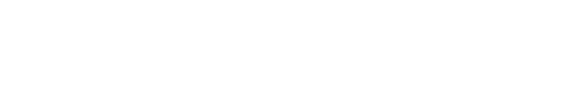

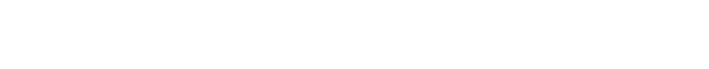

وكلكن تلخهص التنائج فيما يلى:

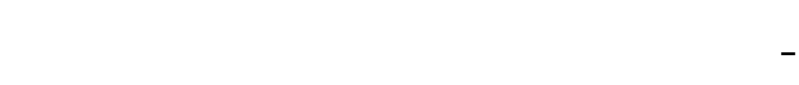

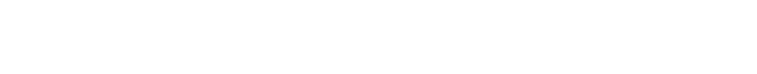

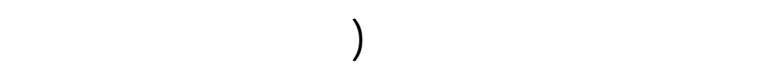

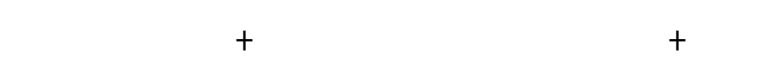

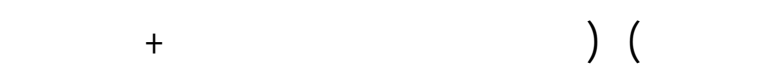

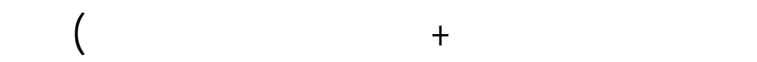

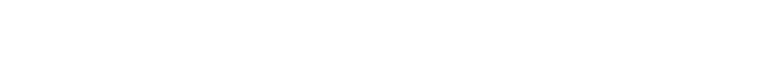
وأعلى عدد من الثمار على الشجرة وأعلى [صولاً.

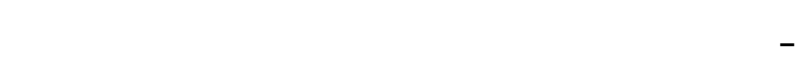

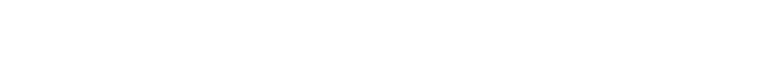
الثمار. قد زادت [ـوضة عصل] الثمار وكذا سنه إلواد الصلة الذائة

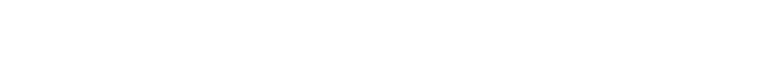

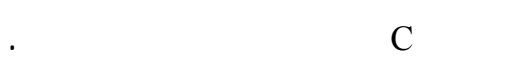

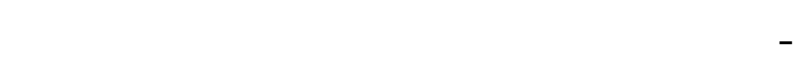
تينة[ملهلات اللش مقارة بالكترول

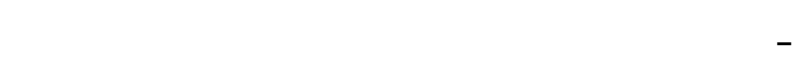

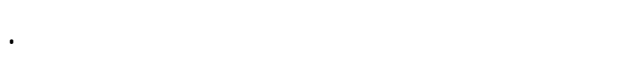

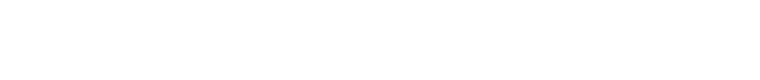

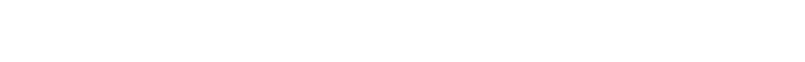

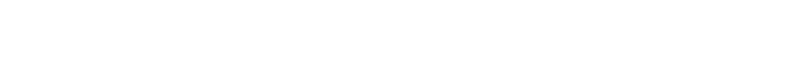

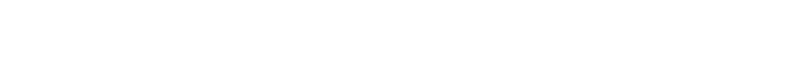

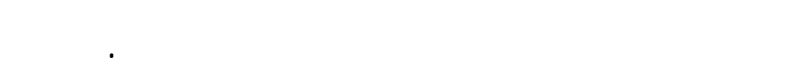

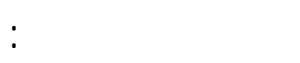
- كترول (رشتصاء الصنبورفظ).

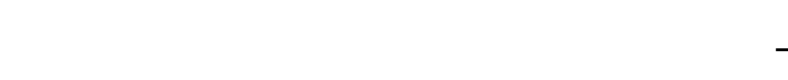

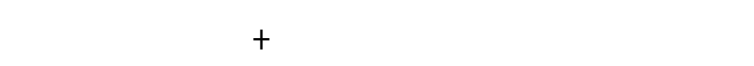

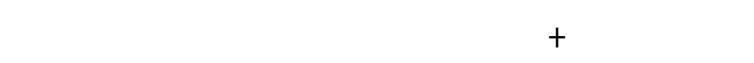

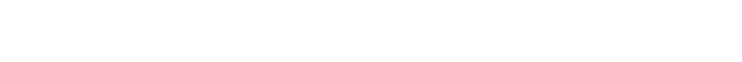
مايوو · ا يونه و · ا يوليو على الزتيب. 1.

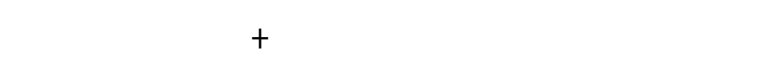

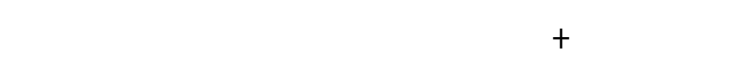
فن الهواعيد الم ذكرتساقَاً. لستخدت لُشجار مكتمة النمو وكمرها السنوات من الآتقل أبوسره لهاعومة على ألل التاريخ وملـركة على مسلة 0 متر.

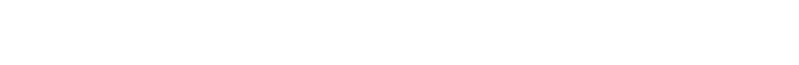

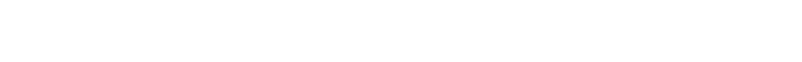
مقع هنه التجرة. 